Ciniviz, G., Mutlu, C. (2020): Effectiveness of some native diatomaceous earth against maize weevil, Sitophilus zeamais (Coleoptera: Curculionidae), under controlled conditions. Agriculture and Forestry, 66 (4): 151-162.

DOI: 10.17707/AgricultForest.66.4.12

Ganime CìviVIZZ ${ }^{1}$, Çetin MUTLU ${ }^{* 2}$

\title{
EFFECTIVENESS OF SOME NATIVE DIATOMACEOUS EARTH AGAINST MAIZE WEEVIL, SITOPHILUS ZEAMAIS (COLEOPTERA: CURCULIONIDAE), UNDER CONTROLLED CONDITIONS
}

\section{SUMMARY}

The Maize weevil, Sitophilus zeamais Motchulsky (Coleoptera: Curculionidae), is one of important pests of storage maize in Turkey. Laboratory experiments were carried out to investigate the effect of two local diatomaceous earth (Aydin and Ankara) and Silicosec ${ }^{\circledR}$ (Biofa, Germany) against S. zeamais adults at 25 and $30^{\circ} \mathrm{C}$ and $50-65 \%$ relative humidity. Maize grains (cultivar Decalp 6664) were treated with three doses of DEs (1000, 1500 and 2000 ppm) and untreated seeds were regarded as control. The dead adult counts were made 2 , 3, 5, 7, 14 and 21 days after DEs. The progeny of S. zeamais was determined separately for each treatment after 60 days from end of the experiment. The highest mortality (100\%) of the maize weevil was observed with 2000 ppm Ankara DE on $14^{\text {th }}$ day after application at $25^{\circ} \mathrm{C}$, which was followed by Aydin and SilicoSec ${ }^{\circledR}$ DEs (99.0 and 90.1\%). The insecticidal activity of native DEs increased with increasing application dose, exposure time and temperature. The highest insecticidal activity at $30{ }^{\circ} \mathrm{C}$ was determined for Ankara and Aydin DEs with 2000 ppm on $14^{\text {th }}$ day $(100 \%)$, followed by SilicoSec ${ }^{\circledR}(97.9 \%)$. All doses of Ankara DE had the highest insecticidal activity than rest of the DEs examined. New adult emergence (F1 offspring) was recorded in all DEs treatments; however, emergence was very low than control treatment. It is concluded that the native DEs (Ankara and Aydin) are very effective and promising against $S$. zeamais adults and might be used for its successful control in storage maize.

Keywords: Diatomaceous earth, Sitophilus zeamais, efficacy, storage maize, pest, mortality

\section{INTRODUCTION}

Storage grain pests, mainly beetles and moths, such as Sitophilus spp. (Coleoptera: Curculionidae), Tribolium spp. (Coleoptera: Tenebrionidae), Rhyzopertha dominica (Coleoptera: Bostrychidae), Trogoderma granarium Everts (Coleoptera: Dermestidae) and Oryzaephilus surinamensis Linnaeus

\footnotetext{
${ }^{1}$ 1Ministry of Agriculture and Forestry Şırnak Directorate of Provincial Agriculture and Forestry, Şırnak, Turkey

2*Harran University Faculty of Agriculture Plant Protection Department Şanlıurfa, Turkey (corresponding author: cetinmutlu21@hotmail.com)

Notes: The authors declare that they have no conflicts of interest. Authorship Form signed online.

Recieved:30/09/2020

Accepted:18/1 1/2020
} 
(Coleoptera: Silvanidae) are especially responsible for weight, germination of stored grains and cause losses up to 100\% in Turkey (Özar and Yücel, 1982; Özer et al., 1989; Iş1kber et al., 2005).

The maize weevil, Sitophilus zeamais Motchulsky (Coleoptera: Curculionidae), is one of important storage pest on maize in Turkey (Yildirım et al., 2012; Karaağaç and Konuş, 2015) as well as other countries (Trone, 1994; Rees, 2004; Ojo and Omoleye, 2016). The pest also cause problem on small grains for example wheat, barley, sorghum, millet and causes significant quantitative and qualitative damage to storage grains and grains can weight loss up to $90 \%$ for not treated storage maize (Giga et al. 1991; Y1ldırım, 2012; Ojo and Omoleye, 2016). Insecticides are mainly used for its control in Turkey (Karaağaç and Konuş, 2015) as well as biological control and botanical insecticides among others (Akob and Ewete, 2007). Besides, several alternatives control methods (natural products such as, palm oil, tobacco extract, leaf essential oils, seed extracts and inert dusts) have been studied against (Foua-Bi, 1993; Korunic, 1998; Owusu, 2001; Doumbia et al., 2014) including S. zeamais.

Dusts, such as diatomaceous earth, are known insecticidal or repellant activity products and effectively controls most species of insect pests of storage products (Ebeling, 1971; Sousa et al., 2013). Diatomaceous earth affects larvae and adults, stick to insect's body parts as they move on their surface or inside the treated grain mass (Kavallieratos et al., 2007; Rojht et al., 2010; Shams et al., 2011; Sousa et al., 2013). When dust contacts with insects, it causes the removal of the layer of wax from insect cuticle, bringing about their death by dessication (Rojht et al., 2010). Besides, this product is extremely stable and has low toxic effect on mammalian, little potential for insect resistance as well as a good residual effect (Eldridge,1964; Ebeling,1971; Korunic,1998). Turkey has a huge and good quality diatomaceous earth reserve (125 million tons) and most of them geological deposits occur in some regions (especially Center Anatolia, Aegean region) of Turkey (Çetin and Taş, 2012). The regional deposits of DEs in Turkey, their low cost, easy availability and use warrant their usage as grain protectants. Although abundant and high-quality DEs reserves exist in Turkey, these have not extensively been evaluated for their potential utility in controlling storage products pest.

Many studies have been conducted in Turkey and other countries to determine the insecticidal, biological and repellent activity of native and trade DEs against storage product pests (Korunic, 1998; Masiiwa, 2004; Ferizli and Beris, 2005; Athanassiou et al., 2004; Sousa et al., 2013; Doumbia et al, 2014; Ertürk and Emekçi, 2014; Wakil et al., 2015; Alkan et al., 2019; Şen et al., 2019; Kılıç and Mutlu, 2020). Whereas, biological efficacy and dose studies of various DEs have been conducted such as on wheat, rice and corn related to $S$. oryzae and $S$. granarius species in Turkey, there is no literature available related to efficacy of local DEs for $S$. zeamais on storage corn kernels. In this study, some native diatomaceous earth from Aydin and Ankara provinces were evaluated for efficacy against $S$. zeamais in the laboratory-controlled conditions in 2020. 


\section{MATERIAL AND METHODS \\ Diatomaceous Earth (DE) formulations}

Three diatomaceous earth (DEs) (two natives, i.e., Ankara, Aydın and imported, i.e., SilicoSec ${ }^{\mathbb{B}}$ ) were used in the study. The DE formulations were given in Table 1.

Table 1. Diatomaceous earth formulations used in the study.

\begin{tabular}{|c|c|c|c|c|c|c|}
\hline $\mathrm{DE}^{*}$ & $\begin{array}{l}\mathrm{SiO}_{2} \\
(\%)\end{array}$ & $\mathrm{Al}_{2} \mathrm{O}_{3}$ & $\mathrm{Fe}_{2} \mathrm{O}_{3}$ & $\mathrm{CaO}$ & $\mathrm{Na}_{2} \mathrm{O}$ & $\begin{array}{l}\text { Particle diameter } \\
\text { size }(\mu \mathrm{m})\end{array}$ \\
\hline Ankara & 92.8 & 4.2 & 1.5 & 0.3 & - & $8-12 \mu$ \\
\hline Aydin & 94.2 & 4.6 & 1.6 & 0.3 & - & $8-12 \mu$ \\
\hline SilicoSec ${ }^{\circledR * *}$ & 92.0 & 3 & 1 & - & 1 & $8-12 \mu$ \\
\hline
\end{tabular}

*DE: Diatomaceous earth

**A sample of dry formulation of Silicosec ${ }^{\circledR}$ was obtained from Biofa GmbH, Germany.

\section{Test insects}

Sitophilus zeamais adults were obtained from cultures maintained in the Entomology Laboratory of Plant Protection Central Research Institute Ankara, Turkey. The adults were reared in sterile $2-\mathrm{L}$ transparent plastic jars on maize grains in incubators maintained at about $25 \pm 1{ }^{\circ} \mathrm{C}$ and $65 \pm 5 \%$ relative humidity and 16:8 h (L: D) in Insectarium of Plant Protection Department, Agriculture Faculty, Harran University. Maize grains were kept in the deep freezer at $-18{ }^{\circ} \mathrm{C}$ at least 7 days to prevent contamination. The jars were not filled to the brim for allowing free air circulation and respiration. Approximately, 250-300 mixed-sex adult individuals were introduced in the jars. The adults on the maize grains were vacuumed after 24 hours for obtaining 1-day-old new adults later. The newly emergence adults were observed at $\sim 35-40$ days after. Emerged adults were collected with an aspirator and used in experiments when they were 1 to 7 days old.

\section{Laboratory bioassay}

Bioassay studies were conducted according to randomized parcel design with four replicates at two temperatures $\left(25\right.$ and $\left.30 \pm 1^{\circ} \mathrm{C}\right), 50-65 \% \mathrm{RH}$. Three doses of local (Ankara and Aydin) and SilicoSec ${ }^{\circledR}$ DE formulation (1000, 1500 and $2000 \mathrm{ppm}$ (mg DE/kg maize grain) were used. Untreated maize grains were considered as the control. For each dose, $100 \mathrm{~g}$ maize grains were used in 1-liter volume plastic jars. The jars were sealed and shaken manually for $1 \mathrm{~min}$ to distribute DE equally. Thirty $S$. zeamais adults were introduced in each jar and the insects were kept in controlled condition insectarium rooms at 25 and $30 \pm 1^{\circ} \mathrm{C}$. The numbers of living and dead adults were recorded after $2,3,5,7,14$ and 21 days respectively.

\section{Effect of diatomaceous earth on $\mathrm{F} 1$ progeny}

The dead and living adult insects were removed 21 days after the initiation of laboratory bioassay. The same jars (infested maize grains) were kept at 25 and $30 \pm 1{ }^{\circ} \mathrm{C}$ and $65 \pm 5 \%$ relative humidity condition to allow oviposited eggs to hatch 
and develop. Then newly emerged adults were counted. Inhibition rate was calculated according to the formula below.

IR\% : Inhibition rate

$$
\mathrm{IR}=(\mathrm{Cn}-\mathrm{Tn}) / \mathrm{Cn} * 100
$$

$\mathrm{Cn}$ : Number of newly emerged insects in the untreated (control) jar

Tn : Number of newly emerged insects in the treated jar.

\section{Statistical Analysis}

All data were converted into percent mortality and subjected to arcsine scale followed by correction of cumulative mortality percentage for the corresponding control mortality (Abbott, 1925). Analysis of variance was conducted to assess the effect of concentration, time of exposure and their interaction with the insect mortalities. The differences among treatments were analyzed by means of Tukey multiple comparison tests $(\mathrm{p}<0.01)$. All statistical analyses were conducted with Jump (Version 7) package program.

\section{RESULTS}

The mortality varied within DEs and their doses. The highest mortality was recorded at higher DEs dose (2000 ppm/100g maize grains) at 25 and $30^{\circ} \mathrm{C}$, while minimum mortality was obtained with lower dose. The lowest mortality after $2^{\text {nd }}$ day was $31.12,36.09$ and $13.33 \%$ with 2000 ppm dose of Ankara, Aydın and SilicoSec ${ }^{\circledR}$ DEs, respectively at $25^{\circ} \mathrm{C}$ (Table 2).

Table 2. Efficacy of different doses of three diatomaceous earth against Sitophilus zeamais adults at $25^{\circ} \mathrm{C}$

\begin{tabular}{llllllll}
\hline \multicolumn{7}{c}{ Mortality (\%) } \\
\hline DE & Treatments & 2. DAT & 3. DAT & 5. DAT & 7. DAT & 14. DAT & 21. DAT \\
\hline Ankara & Control & $0.83 \mathrm{a}$ & $0.83 \mathrm{a}$ & $0.83 \mathrm{a}$ & $0.83 \mathrm{a}$ & $5.83 \mathrm{a}$ & $13.33 \mathrm{a}$ \\
Ankara & $1000 \mathrm{ppm}$ & $3.33 \mathrm{~b}$ & $10.08 \mathrm{a}$ & $29.45 \mathrm{~b}$ & $38.99 \mathrm{~b}$ & $48.24 \mathrm{~b}$ & $75.70 \mathrm{~b}$ \\
Ankara & $1500 \mathrm{ppm}$ & $26.87 \mathrm{c}$ & $62.93 \mathrm{~b}$ & $84.08 \mathrm{c}$ & $89.08 \mathrm{c}$ & $95.33 \mathrm{c}$ & $100.00 \mathrm{~b}$ \\
Ankara & $2000 \mathrm{ppm}$ & $31.12 \mathrm{c}$ & $65.54 \mathrm{~b}$ & $91.66 \mathrm{c}$ & $96.60 \mathrm{c}$ & $100.00 \mathrm{c}$ & $100.00 \mathrm{~b}$ \\
\hline \multicolumn{7}{c}{ Mortality (\%) } \\
\hline Aydın & Control & $0.83 \mathrm{a}$ & $0.83 \mathrm{a}$ & $0.83 \mathrm{a}$ & $0.83 \mathrm{a}$ & $4.16 \mathrm{a}$ & $10.00 \mathrm{a}$ \\
Aydın & $1000 \mathrm{ppm}$ & $5.86 \mathrm{ab}$ & $17.58 \mathrm{a}$ & $30.20 \mathrm{~b}$ & $39.51 \mathrm{~b}$ & $54.89 \mathrm{~b}$ & $67.40 \mathrm{~b}$ \\
Aydın & $1500 \mathrm{ppm}$ & $15.91 \mathrm{~b}$ & $46.89 \mathrm{~b}$ & $79.02 \mathrm{c}$ & $87.47 \mathrm{c}$ & $93.98 \mathrm{c}$ & $99.16 \mathrm{c}$ \\
Aydın & $2000 \mathrm{ppm}$ & $36.09 \mathrm{c}$ & $71.35 \mathrm{~b}$ & $90.69 \mathrm{c}$ & $93.25 \mathrm{c}$ & $99.03 \mathrm{c}$ & $100.00 \mathrm{c}$ \\
\hline \multicolumn{7}{c}{ Mortality (\%) } \\
\hline SlicoSec c Control & $0.00 \mathrm{a}$ & $0.00 \mathrm{a}$ & $0.00 \mathrm{a}$ & $0.00 \mathrm{a}$ & $6.66 \mathrm{a}$ & $10.83 \mathrm{a}$ \\
SlicoSec & $1000 \mathrm{ppm}$ & $2.50 \mathrm{a}$ & $3.33 \mathrm{a}$ & $10.83 \mathrm{~b}$ & $15.00 \mathrm{~b}$ & $38.28 \mathrm{~b}$ & $84.12 \mathrm{~b}$ \\
SlicoSec & $1500 \mathrm{ppm}$ & $10.00 \mathrm{~b}$ & $27.50 \mathrm{~b}$ & $51.66 \mathrm{~b}$ & $60.00 \mathrm{c}$ & $90.13 \mathrm{c}$ & $99.10 \mathrm{c}$ \\
SlicoSec & $2000 \mathrm{ppm}$ & $13.33 \mathrm{~b}$ & $28.33 \mathrm{~b}$ & $60.00 \mathrm{~b}$ & $77.50 \mathrm{~d}$ & $91.06 \mathrm{c}$ & $100.00 \mathrm{c}$ \\
\hline
\end{tabular}

*Different letters in the same column indicate statistically different from each other $(\mathrm{P}<0.05)$

DAT: Day after treatment 
Increasing of exposure time resulted increased $S$. zeamais adult mortality. The 1000 ppm dose of all DEs was insufficient, mortality increased significantly 5 days after treatment (DAT) with $1500 \mathrm{ppm}$ and reached 84.08\% with Ankara DE. The efficacy of Aydin DE was similar to Ankara DE (Table 2). After 7th day, 2000 ppm dose of Ankara and Aydın DEs exhibited high mortality (96.60 and $93.25 \%$ ), while mortality with the same dose of SilicoSec ${ }^{\circledR}(77.50 \%)$ was lower. Insecticidal activity was >90\% with 1000 ppm; however, 100\% mortality was recorded with 2000 ppm dose of Ankara DE 14 DAT. However, SilicoSec ${ }^{\circledR}$ did not reach $100 \%$ mortality with all concentrations. The mortality rate at 21 DAT was $100 \%$ with 1000 ppm doses of all DEs. The mortality with 1000, 1500 and $2000 \mathrm{ppm}$ doses of all DEs at $30{ }^{\circ} \mathrm{C}$ was substantially greater than control at 3 DAT. A considerable increase in mortality was observed with increasing duration in control treatment but remained the lowest (Table 2).

The mortality percentages of $S$. zeamais adults at 2, 3, 5, 7, 14 and 21DAT at different concentrations of Ankara, Aydın and SilicoSec ${ }^{\circledR}$ DEs at $30{ }^{\circ} \mathrm{C}$ are shown in Table 3.

Table 3. Efficacy of different doses of three diatomaceous earth against Sitophilus zeamais adults at $30^{\circ} \mathrm{C}$

\begin{tabular}{llllllll}
\hline \multicolumn{7}{c}{ Mortality (\%) } \\
\hline DE & Treatments & 2. DAT & 3. DAT & 5. DAT & 7. DAT & 14. DAT & 21. DAT \\
\hline Ankara & Control & $1.66 \mathrm{a} *$ & $2.50 \mathrm{a}$ & $3.33 \mathrm{a}$ & $4.16 \mathrm{a}$ & $16.66 \mathrm{a}$ & $29.99 \mathrm{a}$ \\
Ankara & $1000 \mathrm{ppm}$ & $28.79 \mathrm{~b}$ & $66.77 \mathrm{~b}$ & $88.81 \mathrm{~b}$ & $89.44 \mathrm{~b}$ & $98.81 \mathrm{~b}$ & $100.00 \mathrm{~b}$ \\
Ankara & $1500 \mathrm{ppm}$ & $48.94 \mathrm{bc}$ & $77.15 \mathrm{~b}$ & $89.85 \mathrm{~b}$ & $93.96 \mathrm{~b}$ & $99.13 \mathrm{~b}$ & $100.00 \mathrm{~b}$ \\
Ankara & $2000 \mathrm{ppm}$ & $53.45 \mathrm{c}$ & $87.26 \mathrm{~b}$ & $97.38 \mathrm{~b}$ & $97.38 \mathrm{~b}$ & $100.00 \mathrm{~b}$ & $100.00 \mathrm{~b}$ \\
\hline \multicolumn{7}{c}{ Mortality (\%) } \\
\hline Aydin & Control & $0.00 \mathrm{a}$ & $4.99 \mathrm{a}$ & $8.33 \mathrm{a}$ & $8.33 \mathrm{a}$ & $17.50 \mathrm{a}$ & $30.83 \mathrm{a}$ \\
Aydın & $1000 \mathrm{ppm}$ & $35.83 \mathrm{~b}$ & $61.36 \mathrm{~b}$ & $78.90 \mathrm{~b}$ & $84.42 \mathrm{~b}$ & $92.76 \mathrm{~b}$ & $98.33 \mathrm{~b}$ \\
Aydın & $1500 \mathrm{ppm}$ & $69.16 \mathrm{c}$ & $83.24 \mathrm{c}$ & $96.39 \mathrm{bc}$ & $97.29 \mathrm{bc}$ & $98.10 \mathrm{~b}$ & $100.00 \mathrm{~b}$ \\
Aydin & $2000 \mathrm{ppm}$ & $70.83 \mathrm{c}$ & $86.75 \mathrm{c}$ & $97.32 \mathrm{c}$ & $98.21 \mathrm{c}$ & $100.00 \mathrm{~b}$ & $100.00 \mathrm{~b}$ \\
\hline \multicolumn{7}{c}{ Mortality (\%) } \\
\hline SlicoSec & Control & $0.00 \mathrm{a}$ & $3.33 \mathrm{a}$ & $6.66 \mathrm{a}$ & $6.66 \mathrm{a}$ & $23.33 \mathrm{a}$ & $40.00 \mathrm{a}$ \\
SlicoSec & $1000 \mathrm{ppm}$ & $4.16 \mathrm{ab}$ & $9.48 \mathrm{a}$ & $33.83 \mathrm{~b}$ & $51.11 \mathrm{~b}$ & $80.40 \mathrm{~b}$ & $83.61 \mathrm{~b}$ \\
SlicoSec & $1500 \mathrm{ppm}$ & $4.16 \mathrm{ab}$ & $23.07 \mathrm{~b}$ & $42.19 \mathrm{bc}$ & $63.26 \mathrm{bc}$ & $85.54 \mathrm{~b}$ & $98.68 \mathrm{~b}$ \\
SlicoSec & $2000 \mathrm{ppm}$ & $12.50 \mathrm{~b}$ & $31.13 \mathrm{~b}$ & $58.67 \mathrm{c}$ & $78.44 \mathrm{c}$ & $97.95 \mathrm{~b}$ & $98.75 \mathrm{~b}$ \\
\hline
\end{tabular}

*Different letters in the same column indicate statistically different from each other $(\mathrm{P}<0.05)$

DAT: Day after treatment

Exposure time of insects to different DEs concentrations had significant effects $(\mathrm{P}<0.01)$ on mortality of $S$. zeamais adults at $30{ }^{\circ} \mathrm{C}$ (Table 3$)$. Increasing DEs doses and exposure time resulted in increased mortality. The mortality after $72 \mathrm{~h}$ was 87.26 and $86.75 \%$ for Ankara and Aydin DEs, respectively with 2000 ppm dose. SilicoSec ${ }^{\circledR}$ caused very low mortality $31.13 \%$ with same exposure time. 
The highest mortality (97.3\%) was recorded with $2000 \mathrm{ppm}$ concentration of Ankara and Aydin DEs on $5^{\text {th }}$ and $7^{\text {th }}$ DAT, and reached $100 \%$ on $14^{\text {th }}$ DAT, while SilicoSec ${ }^{\circledR}$ caused 58.67 and $78.44 \%$ mortality on 5 and $7^{\text {th }}$ DAT, respectively. The highest mortality $(98.75 \%)$ for SilicoSec ${ }^{\mathbb{B}}$ was noted 21 DAT and did not reach $100 \%$ with any application doses. Mortality in the untreated control remained constant after the insect exposure to untreated maize grains.

Different DEs and application doses showed different suppression effects on the progeny production of $S$. zeamais. After the long storage period (60 days), F1 adult emergence was recorded from all DEs and their all concentrations. The highest number of insects emerged from Aydın, Ankara and SilicoSec ${ }^{\circledR}$ were 30, 26.5 and 15.5 adults respectively in the lower concentration treatment $(1000 \mathrm{ppm})$ at $25{ }^{\circ} \mathrm{C}$. The $\mathrm{F} 1$ adult numbers were decreased with increasing applications doses (1500 and 2000 ppm), which were 1, 2.5 and 7.8 adults for Ankara, Aydın and SilicoSec ${ }^{\circledR}$, respectively at 2000 ppm (Figure 1).

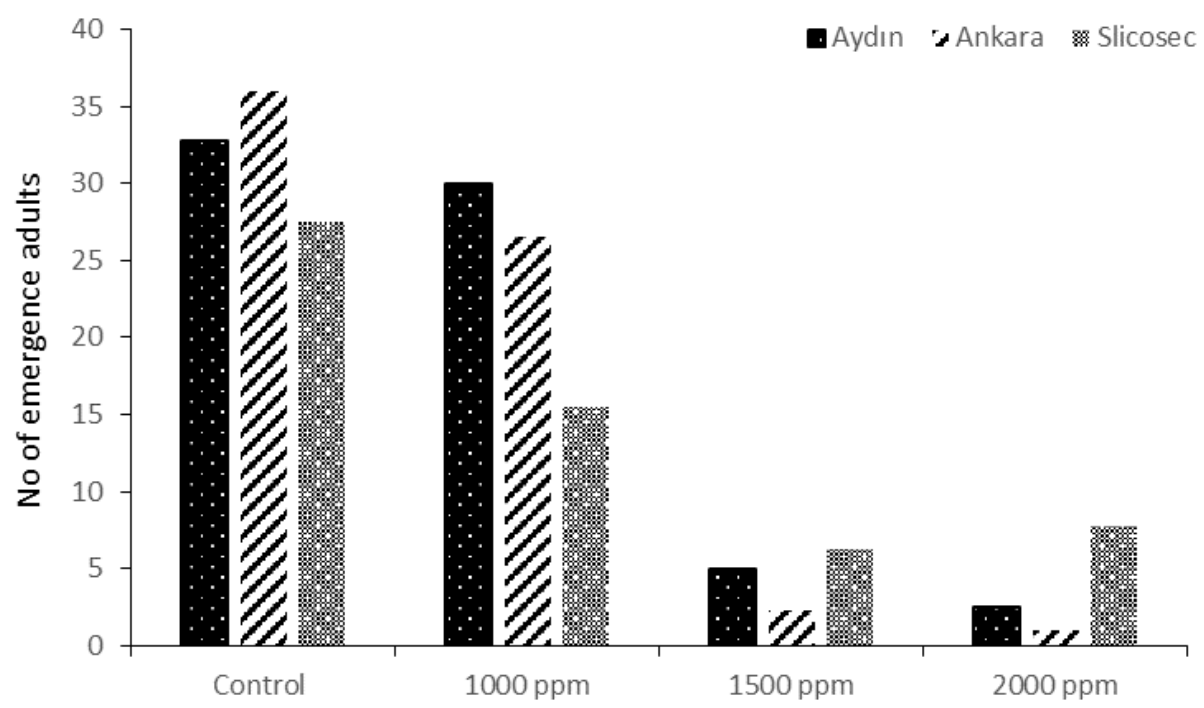

Figure 1. Progeny assessment after 60 days of Sitophilus zeamais exposure to the various $\mathrm{DE}$ at $25^{\circ} \mathrm{C}$

Unlike the data shown in Figure 1 of $25^{\circ} \mathrm{C}, \mathrm{F} 1$ adult emergence was very low with all doses of tested DEs with no differences between all DEs at $30{ }^{\circ} \mathrm{C}$. The number of insects emerged, at the end of the exposure period of 60 days, reduced with the increasing DE doses (Figure 2).

The highest dose (2000 ppm) of Ankara and Aydın DEs was very effective in terms of suppression of F1 production (Figure 2). The number of insects emerged from grains treated with DEs at 1500 and $2000 \mathrm{ppm}$ at $30^{\circ} \mathrm{C}$ was substantially lesser than the grains in the control 


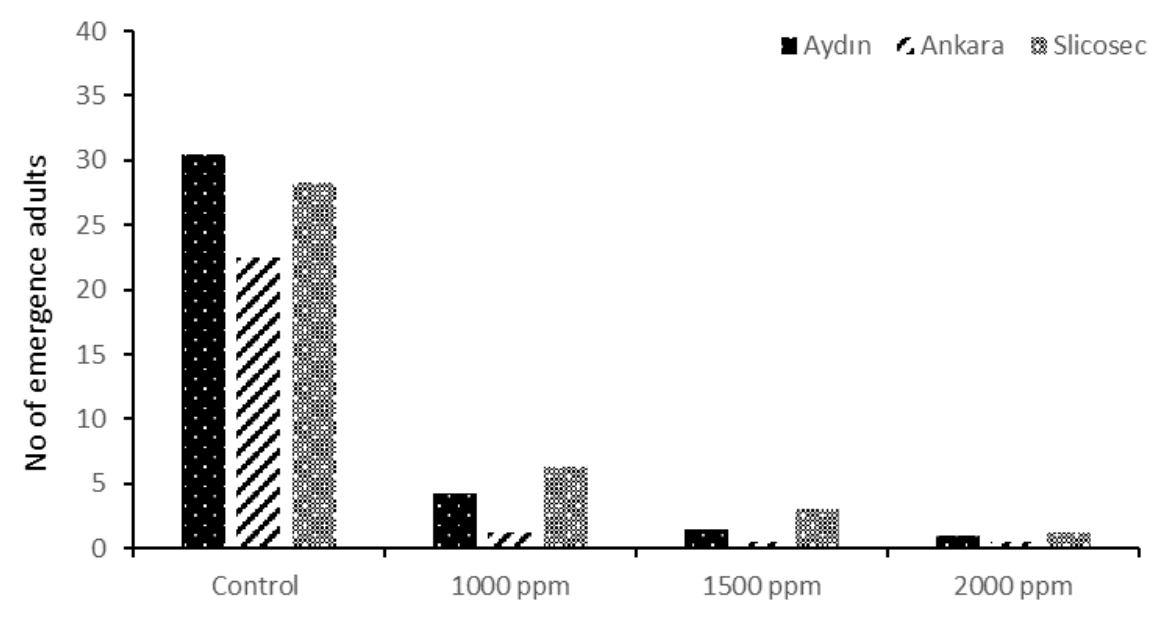

Figure 2. Progeny assessment after 60 days of Sitophilus zeamais exposure to the various $\mathrm{DE}$ at $30^{\circ} \mathrm{C}$

\section{DISCUSSION}

The purpose of this study was to investigate the effect of two native diatomaceous earth (DEs) on mortality of $S$. zeamais adults under controlled conditions. The results of the study indicated that the efficacy of all DEs was considerably influenced by doses, time of exposure, temperature and type of DE formulations. Similar results have been reported by previous researchers (Korunic, 1998; Arthur, 2001; Arnaud et al., 2005; Vayias et al., 2006; Shams et al., 2011; Alkan et al, 2019; Şen et al., 2019; Kılıç and Mutlu, 2020). These studies indicated increased mortality of storage product pests exposed to inert dusts with increasing exposure time. Exposure time of two-day of DEs was not enough to obtain significant mortality with tested DEs in the current study. However, the mortality rate was increased at three DEs, as increased day of exposure after $5^{\text {th }}$ day and reached higher mortality rate on $14^{\text {th }}$ day at 25 and $30^{\circ} \mathrm{C}$ in the study. Similar result reported by Arthur (2001) who stated that mortality of Oryzaephilus surinamensis L. generally increased as exposure interval and temperature increased. Extended exposure time may be needed to increase mortality in adults, because more dust particles would be trapped by their bodies, losing more water and causing death by desiccation (Fields and Korunic, 2000; Arthur, 2001; Rigaux et al., 2001; Shams et al.2011).

The effectiveness of DEs increased with higher doses and temperature. This effect shows that the mortality of insects is dependent on the conditions in which the grains are exposed to DEs (Sousa et al., 2013). The particles and size of DEs have abrasive peculiarities but more importantly the ability to absorb lipid molecules from the cuticle of the insects and subsequently, in water loss, dehydration and death (Quarles and Winn, 1996; Korunic, 1998; Subramanyam 
and Roelsi, 2000). Altough the particles size of all DEs is very close, SilicoSec ${ }^{\circledR}$ had moderate effect on $S$. zeamais adults. The results indicated that DEs from different locations vary in their efficacy against the maize weevil. This has also been explained by Korunic (1997) and Golob (1997) that DEs from different geological locations have different efficacies and DEs from marine areas are the most common but less efficacious.

The mortality was considerably increased with increasing temperature and was higher at $30^{\circ} \mathrm{C}$ than $25^{\circ} \mathrm{C}$. The earlier studies on the influence of temperature on the efficacy of some local and traded DEs against storage pest ( $S$. oryzae, $T$. confusum and $R$. dominica) indicated that increasing temperature resulted in increasing insecticidal efficiency against $S$. oryzae adults (Fields and Korunic, 2000; Arthur, 2002; Athanassiou et al., 2005; Vassilakos et al., 2006; Rojht et al., 2010, Şen et al., 2019). The results of the current study agree with Vassilakos et al. (2006) who reported that insecticidal efficacy of SilisoSec ${ }^{\mathbb{B}}$ against $S$. oryzae increased with increasing temperature. However, increased temperature would also increase feeding and therefore moisture replacement through the food and production of metabolic water. The synthesis of cuticular waxes may be faster at higher temperatures because of temperature effects on the biochemical pathways (Turnbull and Harris, 1986; Şen et al., 2019). High temperatures stimulate the movement of insects within the grain mass, allowing them greater contact with DEs. In addition, water loss is likely to be increased at higher temperatures (Arthur, 2001; Fields and Korunic, 2000).

The total mortality was influenced by DE types under both temperatures. The local DEs, Ankara and Aydın, showed $>90 \%$ mortality 5 DAT, while SilicoSec ${ }^{\circledR}$ caused $\sim 60 \%$ mortality at $25^{\circ} \mathrm{C}$. Smilar results were obtained at $30^{\circ} \mathrm{C}$ which clearly indicated that the local DEs were effective than $\mathrm{SilicoSec}^{\circledR}$ against the maize weevil. The differences between $\operatorname{SilicoSec}^{\circledR}$ and local DEs can be explained by the differences in physical, morphological and chemical characters of DEs. Kıliç and Mutlu (2020) found the highest biological activity with local DE Aydın on Trogoderma granarium Everts larvae followed by Ankara DE, while SilicoSec ${ }^{\circledR}$ had the lowest activity larvae at $30^{\circ} \mathrm{C}$. However, Alkan et al., (2019) reported that the local DE Turco000 caused $100 \%$ mortality to Acanthoscelides obtectus Say. adults on chickpea at 1000 ppm 4 DAT and can be used as a valuable tool for bean weevil suppression in storage product pest management programs. Besides, complete mortality of $T$. confusum and $S$. oryzae can be achieved at lower concentrations ranging from 500 to $900 \mathrm{ppm}$ local DE formulation (ACN-1) and this DE has potential to be used for control of storagegrain insects reported by Şen et al. 2019.

The study results showed that at least $1500 \mathrm{ppm}$ dose at $30{ }^{\circ} \mathrm{C}$ caused $>90 \%$ mortality 5 DAT. The results of the present study indicated that complete mortality of $S$. zeamais achieved at higher concentrations, ranging from 1500 to $2000 \mathrm{ppm}$. These results do not agree with Masiiwa (2004) who reported different results with local African DEs on the maize weevil. Insect mortality caused by DEs is attributed to the dehydration provoked by the abrasiveness of the small 
particles of this inert dust and by adsorption of oils in the body of the insect, which breaks the layer of wax on the epicuticle, exacerbating the fatal loss of water reported by Subramanyam and Roesli (2000). Therefore, at higher concentrations, the adsorption of wax and abrasiveness caused by the product occurs faster, causing death in a shorter time compared with low concentrations (Shams et al. 2011). In addition, the higher the concentration of DEs can be the more effective, because dust applied to cover containers and grain surface will be greater chances of the insect picking up the dust to cause enough damage (Masiiwa, 2004). Maize grain surface is rough, and adherence is greater than small grain like wheat, millet which are smooth surface have low adherence.

The number of emerged adults in progeny reduced with increasing temperature, reaching $\sim 5 \%$ at 1500 and $2000 \mathrm{ppm}$ doses of all DEs at 25 and $30^{\circ} \mathrm{C}$. The high mortality was observed for $30^{\circ} \mathrm{C} 5 \mathrm{DAT}$. These results could be due to the fact that higher temperatures might reduce the rate of oviposition and limit the survival of insects and reduce the number of individuals in the progeny (Vardeman et al., 2006). Alkan et al. (2019) reported that there was no progeny production with local DEs, Turco000, Turco004, Turco020 at $200 \mathrm{ppm}$ concentration at the end of 55-day incubation period on C. maculatus. Kılıç and Mutlu (2020) stated that 1000, 1500 and 2000 ppm of local DEs (Aydin and Ankara) applied to wheat resulted low mortalities of $T$. granarium larvae and higher doses did not prevent reproduction.

The results presented in this study suggest that $1500 \mathrm{ppm}$ dose of Aydin DE with high temperatures can be recommended to control the maize weevil with 5 days exposure time.

\section{CONCLUSIONS}

The native diatomaceous earths obtained from local sources (Ankara and Aydın) showed high efficacy against the maize weevil under controlled conditions. The study also indicated that temperature had significant effect on the insecticidal efficacy of local DEs against the maize weevil, S. zeamais. Based on the results of the bioassays, mortality increased with increasing dose and the exposure time. In conclusion local DEs (Ankara and Aydın) have potential to be used for control of maize weevil.

\section{REFERENCES}

Abbott WS. 1925. A method of computing the effectiveness of an insecticide. Journal of Economic Entomology, 18: 265-267.

Akob CA and Ewete FK. 2007. The efficacy of ashes of four locally used plant materials against Sitophilus zeamais (Coleoptera: Curculionidae) in Cameroon. International Journal of Tropical Insect Science, 27 (1): 21-26.

Alkan M, Erturk S, Firat TA, Ciftci E. 2019. Study of Insecticidal and Behavioral Effects and Some Characteristic of Native Diatomaceous Earth against the Bean Weevil, Acanthoscelides obtectus (Coleoptera: Chrysomelıdae). Fresenius Environmental Bulletin, 28(4): 2916-2922. 
Arnaud L, Lang HTT, Brostaux Y and Haubruge E. 2005. Efficacy of diatomaceous earth formulations admixed with grain against populations of Tribolium castaneum. Journal of Stored Product Research, 41: 121- 130.

Arthur FH. 2001. Immediate and delayed mortality of Oryzaephilus surinamensis (L.) exposed on wheat treated with diatomaceous earth: effects of temperature, relative humidity, and exposure interval. Journal of Stored Product Research, 37: 13-21.

Arthur FH. 2002. Survival of Sitophilus oryzae (L.) on wheat treated with diatomaceous earth: impact of biological and environmental parameters on product efficacy. Journal of Stored Product Research, 38: 305-313.

Athanassiou CG, Vayias BJ, Dimizas CB, Kavallieratos NG, Papagregoriou AS and Buchelos C. Th. 2005. Insecticidal efficacy of diatomaceous earth against Sitophilus oryzae (L.) (Coleoptera: Curculionidae) and Tribolium confusum du Val (Coleoptera: Tenebrionidae) on stored wheat: influence of dose rate, temperature and exposure interval. Journal of Stored Products Research, 41: 47-55.

Athanassiou, CG, Kavallieratos NG and Andris NS. 2004. Insecticidal effect of three Diatomaceous earth formulations against adults of Sitophilus oryzae (Coleoptera: Curculionidae) and Tribolium confusum (Coleoptera: Tenebrionidae) on oat, rye and triticale. Journal of Economic Entomology, 97: 2160-2167.

Çetin M and Taş B. 2012. A natural mineral with biological origin: Diatomite. Turkish Science-Research Foundation Science Journal, 5 (2): 28-46.

Doumbia M, Douan G B, Kwadjo KE, Kra DK, Martel V and Dagnogo M. 2014. Effectiveness of diatomaceous earth for control of Sitophilus zeamais (Coleoptera: Curculionidae), Tribolium castaneum and Palorus subdepressus (Coleoptera: Tenebrionidae). Journal of Stored Products Research, 57: 1-5.

Ebeling W. 1971. Sorptive dusts for pest control. Annual Review of Entomology, 16: 123-158.

Eldridge MB. 1964. The effect of ingestion of diatomaceous earth in white rats: a subacute toxicity test. Toxicology and Applied Pharmacology, 6: 284-291.

Ertürk S and Emekçi M. 2014. Using possibilities of diatomaceous earth against stored paddy rice pest the red flour beetle Tribolium castaneum Herbst. Plant Protection Bulletin, 54(3): 211-217.

Ferizli AG and Beris G. 2005. Mortality and F1 progeny of the lesser grain borer (Rhyzopertha dominica (F.)) on wheat treated with diatomaceous earth: Effects of dose, exposure interval and relative humidity. Pest Management Science, 61(11): $1103-1109$.

Fields P and Korunic Z. 2000. The effect of grain moisture content and temperature on the efficacy of diatomaceous earths from different geographical locations against stored-product beetles. Journal of Stored Products Research, 36: 1-13.

Foua-Bi K. 1993. Natural products use in the safeguarding of stocks in Black Africa. In: Thiam, A., Ducommun, G. (Eds.), Natural Protection of the Plants in Africa. EndaEditions, pp. 85-100.

Giga DP, Mutemerewa S, Moyo G and Neeley D. 1991. Assessment and control of losses caused by insect pests in small farmers' stores in Zimbabwe. Crop Protection, 10 (4): 287-292.

Golob P. 1997. Current status and future perspectives for inert dusts for control of stored product insects. Journal of Stored Products Research, 33: 69-79. 
Iş1kber AA, Özdamar HÜ and Karcı A. 2005. Determination of insect species and their infestation rates on stored wheat in Kahramanmaraş and Adiyaman Province. KSU Journal of Science and Engineering, 8 (1): 107-113.

Karaağaç SU and Konuş M. 2015. Determination of organophosphate resistance status and mechanism in Sitophilus zeamais Motschulsky (Coleoptera: Curculionidae) from Turkey. Turkish Journal of Biochemistry, 40(5): 417-422.

Kavallieratos NG, Athanassiou C G, Vayias BJ and Maistrou S. 2007. Influence of temperature on susceptibility of Tribolium confusum (Coleoptera: Tenebrionidae) populations to three modified diatomaceous earth formulations. Florida Entomologist, 90: 616-625.

Kılıç A and Mutlu Ç. 2020. Biological activity of some native diatomaceous earth against Khapra, Trogoderma granarium Everts (Coleoptera: Dermestidae), larvae under laboratory conditions. International Journal of Agricultural and Wildlife Sciences, 6(1), 44-54.

Korunic Z. 1997. Rapid assessment of insecticidal value of diatomaceous earths without conducting bioassays. Journal of Stored Products Research, 33: 219-229.

Korunic Z. 1998. Diatomaceous earths, a group of natural insecticides. Journal of Stored Product Research, 34: 87-97.

Masiiwa P. 2004. Evaluation of African Diatomaceous earths (DEs) As Potential Maize Grain Protectans Against the Maize Weevil (Sitophilus zeamais). Universty of Zimbabwe, Department of Crop Science, 41p.

Ojo JA and Omoloye AA. 2016. Development and life history of Sitophilus zeamais (Coleoptera: Curculionidae) on cereal crops. Advances in Agriculture, 2016:1-8.

Owusu OE. 2001. Effect of some Ghanaian plant components on control of two storedproduct insect pests of cereals. Journal of Stored Product Research, 37: 85-91.

Özar Aİ and Yücel A. 1982. Survey studies on the stored grain pests in the southeast Anatolia region. Plant Protection Bulletin, 22 (2): 89-98.

Özer M, Toros S, Çobanoğlu S, Çınarlı S and Emekçi M. 1989. The description, distribution and habitats of acarina species harmful to stored grains and grain products and dried fruits in İzmir Province. Turkish Journal of Agriculture and Forestry, 3: 1154-1189.

Quarles W and Winn P. 1996. Diatomaceous Earth and Stored Product Pest. IPM Practitioner pp 1-10.

Rees DP. 2004. Insects of Stored Products, CSIRO Publishing.

Rigaux M, Haubruge E and Fields PG. 2001. Mechanisms for tolerance to diatomaceous earth between strains of Tribolium castaneum. Entomologia Experimentalis et Applicata, 101: 33-39.

Rojht H, Horvat A, Athanassiou CG, Vayias BJ, Tomanović Z and Trdan S. 2010. Impact of geochemical composition of diatomaceous earth on its insecticidal activity against adults of Sitophilus oryzae (L.) (Coleoptera: Curculionidae). Journal of Pest Science, 83: 429-436.

Şen R, Işikber AA, Bozkurt H and Sağlam Ö. 2019. Effect of temperature on insecticidal efficiency of local diatomaceous earth against stored-grain insects. Turkish Journal of Entomology, 43(4): 441-450. 
Shams G, Safaralizadeh MH and Imani S. 2011. Insecticidal effect of diatomaceous earth against Callosobruchus maculatus (F.) (Coleoptera: Bruchidae) and Sitophilus granarius (L.) (Coleoptera: Curculionidae) under laboratory conditions. African Journal of Agricultural Research, 6: 5464-5468.

Sousa AH, Faroni LR, Andrade GS, Freitas RS and Pimentel MA. 2013. Bioactivity of diatomaceous earth to Sitophilus zeamais (Coleoptera: Curculionidae) in different application conditions. Revista Brasileira de Engenharia Agrícola e Ambiental, 17(9): 982-986.

Subramanyam BH, Roesli R. 2000. Inert dusts (Eds. BH Subramanyam, DW Hagstrum). Alternatives to pesticides in stored product IPM. Kluwer Academic Publishers, Dordrecht, the Netherlands, pp. 321-380.

Throne JE. 1994. Life history of immature maize weevils (Coleoptera: Curculionidae) on corn stored at constant temperatures and relative humidities in the laboratory. Environmental Entomology, 23 (6): 1459-1471.

Turnbull SA and Harris CR. 1986. Influence of post treatment temperature on the contact toxicity of ten organophosphorus and pyrethroid insecticides to onion maggot adults (Diptera: Anthomyiidae). Proceedings of the Entomological Society of Ontario, 117: 41-44.

Vardeman EA, Arthur FH, Nechols JR and Campbell JF. 2006. Effect of temperature, exposure interval and depth of diatomaceous earth on distribution, mortality, and reproduction of the lesser grain borer, Rhyzopertha dominica (F.) (Coleoptera: Bostrichidae) in stored wheat. Journal of Economic Entomology, 99: 1017-1024.

Vassilakos, TN, Athanassiou CG, Kavallieratos NG and Vayias BJ. 2006. Influence of temperature on the insecticidal effect of Beauveria bassiana in combination with diatomaceous earth against Rhyzopertha dominica and Sitophilus oryzae on stored wheat. Biological Control, 38 (2): 270-281.

Vayias BJ, Athanassiou CG, Kavallieratos NG and Buchelos CTH. 2006. Susceptibility of different European Populations of Tribolium confusum (Coleoptera: Tenebrionidae) to five diatomaceous earth formulations. Journal of Economic Entomolology, 99: 1899-1904.

Wakil W, Ghazanfar MU, Yasin M and Jung Kwon Y. 2015. Efficacy of Metarhizium anisopliae combined with diatomaceous earth against Sitophilus oryzae (Coleoptera: Curculionidae) under laboratory conditions. Revista Colombiana de Entomología, 41 (1): 81-86.

Yildırım E, Emsen B, Aslan A, Bulak Y and Ercisli S. 2012. Insecticidal activity of lichens against the maize weevil, Sitophilus zeamais Motschulsky (Coleoptera: Curculionidae). Egyptian Journal of Biological Pest Control, 22: 151-156.

Y1ldırım E. 2012. Pests of stored products and their control methods. (3th ed.). Erzurum: Atatürk University, Agriculture Faculty Press, No: 191. 